\title{
Kemampuan komunikasi matematis tulis siswa Samin dalam memecahkan masalah geometri
}

\author{
Setyo Riyadi, Kurnia Noviartati, Zainal Abidin * \\ Fakultas Matematika dan Ilmu Pengetahuan Alam, STKIP Al-Hikmah. \\ * Corresponding Author. E-mail: nidiba@gmail.com \\ Submitted: 30 November 2020 | Revised: 30 Maret 2021 | Accepted: 30 Maret 2021 | Available Online: 12 April 2021
}

\begin{abstract}
Abstrak
Keterampilan komunikasi matematis merupakan salah satu tujuan pembelajaran matematika. Tujuan penelitian ini adalah mendeskripsikan kemampuan komunikasi matematis siswa Samin dalam menyelesaikan masalah geometri. Jenis penelitian ini adalah penelitian deskriptif dengan pendekatan kualitatif. Subjek penelitian adalah anggota masyarakat adat Samin yang duduk di kelas VII SMPN 1 Margomulyo. Tahapan penelitian meliputi persiapan, pengumpulan data, analisis data, dan pembuatan laporan. Instrumen penelitian yang digunakan adalah Tes Kemampuan Matematika (TKM), Tes Kemampuan Komunikasi Matematika (TKKM), dan Pedoman Wawancara. Hasil penelitian menunjukkan bahwa keterampilan komunikasi matematika tertulis siswa dalam menulis ide matematika (penggunaan model matematika, rumus atau simbol) dengan jelas dan tepat untuk menyelesaikan suatu masalah tergolong rendah, Keterampilan komunikasi matematis tertulis siswa dalam menulis alasan jawaban yang diberikan adalah relatif rendah, keterampilan komunikasi matematika tertulis siswa dalam menulis ulang gagasan orang lain dengan menggunakan bahasanya sendiri tergolong sedang, dan keterampilan komunikasi matematika tertulis siswa dalam mengungkapkan kembali ide orang lain diklasifikasikan rendah.
\end{abstract}

Kata Kunci: komunikasi matematis, masalah geometri, siswa Samin

\section{Written mathematical communication skills of Samin students in solving geometric problems}

\begin{abstract}
Mathematical communication skills are one of the goals of mathematics learning. The purpose of this study is to describe the mathematical communication ability of Samin students in solving geometric problems. The type of this research was a descriptive study with a qualitative approach. The research subjects were members of the Samin indigenous people who were in Class VII at SMPN 1 Margomulyo. The stages of the research included preparation, data collection, data analysis, and report making. The research instruments used were the Mathematics Ability Test (TKM), the Mathematical Communication Ability Test (TKKM), and Interview Guidelines. The results show that the students 'written mathematical communication skills in writing mathematical ideas (the use of mathematical models, formulas or symbols) clearly and precisely to solve a problem were classified as low.The students' written mathematical communication skills in writing the reasons for the answers given were relatively low, students' written mathematical communication skills in re-writing others' ideas using their own language were moderate, and students' written mathematical communication skills in re-expressing other people's ideas were classified as low.
\end{abstract}

Keywords: mathematical communication, geometric problems, samin students

How to cite:

Riyadi, S., Noviartati, K., \& Abidin, Z. (2021). Kemampuan komunikasi matematis tulis siswa Samin dalam memecahkan masalah geometri. Ethnomathematics Journal, 2(1), 31-37.

https://doi.org/10.21831/ej.v2i1.36192

This is an open access article under the CC-BY-SA license. 


\section{PENDAHULUAN}

Komunikasi merupakan sebuah proses pengiriman dan penerimaan berita antara dua orang atau lebih dengan cara yang tepat sehingga berita dapat tersampaikan. Komunikasi masyarakat di Indonesia tergolong beragam di setiap daerahnya, hal ini disebabkan karena adanya perbedaan suku, bahasa, ras, dan adat istiadat yang ada di masing-masing daerah. Indonesia merupakan negara yang kaya dengan ribuan pulau, aneka budaya, bahasa, suku bangsa, dan sumber daya alam (Adhe, 2014). Menurut Melalatoa (1995) Pulau Jawa sebagai salah satu pulau di Indonesia memiliki beragam suku bangsa yakni Jawa, Baduy, Banten, Cirebon, Naga, Sunda, Bagelen, Banyumas, Nagariung, Bawean, Tengger, Madura, Using, dan Samin. Ragam kehidupan dan adat istiadat di setiap masyarakat suku bangsa dapat memunculkan kemampuan komunikasi matematis dalam bentuk tulis peserta didik di Indonesia yang beragam pula di setiap masyarakat suku bangsa tersebut.

Terdapat kaitan yang menarik antara nilai-nilai kearifan lokal dengan disiplin ilmu matematika. Wahyuni dan Pertiwi (2017) menyatakan bahwa pada tahun 1997 matematikiawan Brazil bernama D' Ambrosio mengemukakan bahwa studi etnomatematika berperan sebagai studi khusus untuk menemukan ide-ide matematika yang ada dalam kebudayaan atau kearifan lokal sebuah masyarakat. Hal ini menunjukkan bahwa ide-ide matematika memiliki peranan dalam menemukan nilai-nilai kearifal lokal pada sebuah masyarakat. Oktafiya (2016) menyatakan bahwa masyarakat adat Samin di dusun Jepang Desa Margomulyo, Kecamatan Margomulyo, Kabupaten Bojonegoro memiliki inisiatif untuk melestarikan kesenian dan kebudayaan yang dimiliki dari sesepuh dan pendiri terdahulu. Hal tersebut ditandai dengan pendirian balai budaya suku Samin sebagai pusat kegiatan kesenian tradisional gamelan dan kerajinan tangan masyarakat adat Samin. Balai budaya suku Samin dapat dilihat pada Gambar 1.
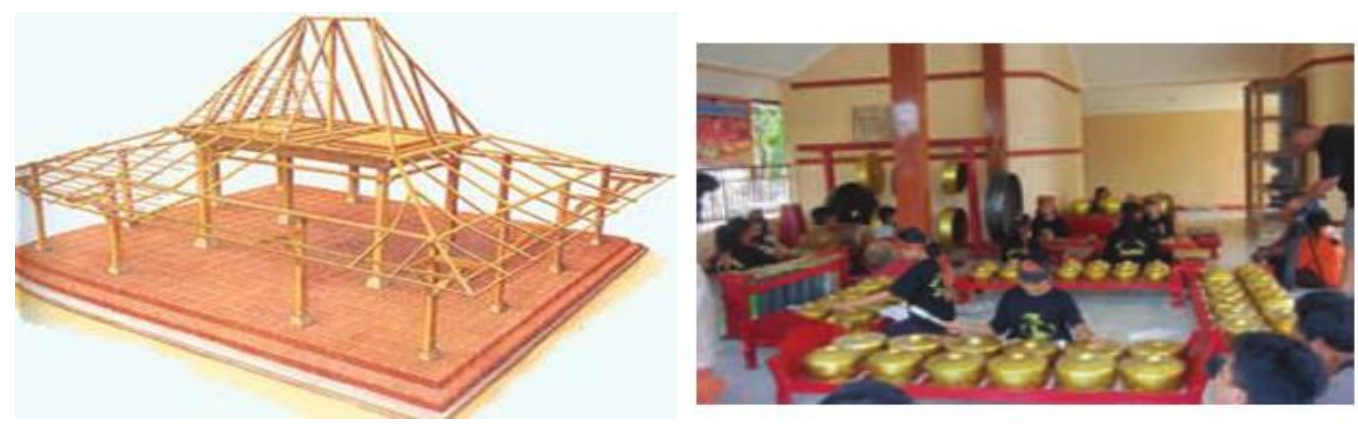

Gambar 1. Balai Budaya Suku Samin

Munawaroh, Ariani, dan Suwarno (2015) menyebutkan bahwa suku Samin merupakan bagian dari suku Jawa dan merupakan suatu bentuk pengelompokan masyarakat yang didasarkan pada ajaran dan pandangan hidup khas atau tertentu dengan komunitas lain (masyarakat Jawa di sekitarnya). Muhlizi (2014) menyatakan bahwa suku Samin berkembang dan menyebar di daerah Blora, Tuban, Kudus, Rembang, Grobogan, Pati, dan Bojonegoro masyarakat Samin masih memegang teguh ajaran yang diturunkan oleh leluhurnya. Ajaran Saminisme berasal dari Samin Surosentiko yang lahir pada tahun pada tahun 1859 di Desa Ploso Kedhiren, Klopodhuwur, Randublatung, Blora, Provinsi Jawa Tengah (Pinasti \& Irenewaty, 2016). Ajaran tersebut berpegang kepada kitab Kalimusada, dengan agama Adam yang diyakninya. Beberapa ajaran yang hingga saat ini masih diyakini adalah larangan memiliki sifat iri, dengki, bertengkar, berbuat jahat, dan dilarang mengambil barang milik orang lain.

Kemampuan komunikasi menjadi salah satu tujuan dalam pembelajaran matematika. Komunikasi yang dimaksud dalam hal ini adalah kemampuan peserta didik dalam mengkomunikasikan gagasan dengan simbol, tabel, diagram, atau media lain untuk memperjelas keadaaan atau masalah dalam pembelajaran matematika (Hodiyanto, 2017). Fahradina, Ansari, dan Saiman (2014) mengemukakan bahwa Kurikulum 2013 menetapkan kemampuan komunikasi sebagai salah satu hal penting dalam pembelajaran matematika. Hal ini menandakan pentingnya kemampuan komunikasi dalam pembelajaran matematika. Zayzafuun (2016) menyatakan bahwa komunikasi dapat dibagi 
menjadi dua jenis, yaitu komunikasi verbal (lisan) dan komunikasi non verbal (tulis). Menurut (Junaedi, 2010) menulis merupakan salah satu jenis komunikasi yang perlu dikembangkan dalam pembelajaran matematika. Komunikasi dalam bentuk tulis dapat menunjukkan proses pembelajaran yang dialami peserta didik sebagai bahan evaluasi hasil pembelajaran. Komunikasi dalam hal ini berkaitan dengan pertukaran ide matematis, penggunaan notasi, istilah, dan simbol dalam pembelajaran matematika.

Komunikasi dalam menyampaikan ide, gagasan, dan alasan matematis kepada orang lain secara lisan dan tulis dapat diartikan sebagai kemampuan komunikasi matematis (Yunianto, 2014). Kemampuan komunikasi matematis peserta didik di Indonesia masih jauh dari harapan, fakta di lapangan menunjukkan komunikasi matematis peserta didik Indonesia tergolong rendah. Hal ini ditandai dengan mayoritas peserta didik Indonesia yang mengalami kesulitan dalam menerjemahkan soal kehidupan sehari-hari ke dalam model matematika (Agustyaningrum, 2012). Berkaitan dengan itu, (Jurotun, 2015) mengungkapkan bahwa mayoritas peserta didik di Indonesia mengalami kesulitan dalam membedakan penggunaan simbol dan lambang matematika. Berdasarkan fenomena tersebut maka peneliti terdorong untuk melakukan penelitian tentang komunikasi matematis tulis peserta didik Samin dalam memecahkan masalah geometri.

Materi segitiga dan segiempat telah menjadi salah satu materi dalam pembelajaran matematika yang dapat digunakan untuk mengetahui kemampuan komunikasi matematis peserta didik. Hal tersebut didukung oleh penelitian Laksananti, Setiawan, dan Setiawani (2017) yang menggunakan materi bangun datar segiempat sebagai instrumen. Selanjutnya pada tahun 2018 Wijayanto, Fajriah, dan Anita (2018) melakukan penelitian dengan menggunakan materi segitiga dan segiempat sebagai instrumen penelitian untuk mengetahui deskripsi kemampuan komunikasi matematis peserta didik SMP di salah satu sekolah di Cimahi. Hal yang membedakan dalam penelitian ini adalah subjek penelitian dengan latar belakang suku tertentu. Keterbaruan dalam penelitian ini dibandingkan dengan penelitian lain adalah penggunaan instrumen penelitian yang mengintegrasikan budaya, adat istiadat, dan kearifan lokal yang dimiliki suku Samin.

Komunikasi matematis tulis menurut Rassia (2016) adalah kemampuan atau keterampilan peserta didik dalam menerjemahkan pengetahuan ke dalam bentuk bahasa simbol, grafik atai gambar, tabel, atau diagram. Kemampuan komunikasi matematis menjadi salah satu tujuan penting dalam pembelajaran matematika yang perlu dikembangkan (Umar, 2012; Wardhani, 2008)(Wardhani, 2008). Hal ini bekenaan dengan proses pemahaman materi matematika yang diberikan oleh guru kepada peserta didik dalam prses pembelajaran matematika. Wijayanto et al. (2018) menyatakan bahwa komunikasi matematis adalah kegiatan memahami materi matematika yang terjadi antara peserta didik dengan sesama peserta didik lainnya maupun peserta didik dengan guru dalam pembelajaran matematika dikelas. Lebih lanjut menurut Hodiyanto (2017) mengungkapkan bahwa komunikasi matematis terdiri atas komunikasi lisan dan komunikasi tulis. Komunikasi lisan dapat berupa diskusi dan menjelaskan, sedangkan komunikasi tulisdapat berupa penggunaan gambar atau grafik, tabel, atau persamaan.

Darkasyi, Johar, dan Ahmad (2014) mengungkapkan bahwa komunikasi matematis merupakan proses dialog timbal balik materi antara peserta didik dan guru dalam pembelajaran matematika yang dilakukan secara lisan maupun secara tertulis. Materi dalam hal ini adalah ide-ide atau gagasan matematis, model matematika, notasi, simbol, definisi, dan rumus dalam pembelajaran matematika. Hal ini berarti dalam proses pembelajaran matematika, peserta didik membutuhkan kemampuan komunikasi matematis yang baik untuk memahami, menerapkan, dan mengevaluasi materi yang telah diberikan oleh guru. Sementara itu, menurut Ardina dan Sa'dijah (2016) komunikasi matematis tulis siswa akan lebih meningkat jika siswa telah mengalami proses pembelajaran yang sesuai. Berdasarkan uraian tersebut kemampuan komunikasi matematis tulis yang dimaksud dalam penelitian ini, yaitu; 1.) Kemampuan peserta didik dalam menuliskan ide yang dimiliki dengan jelas dan tepat; 2.) Kemampuan peserta didik dalam menuliskan alasan untuk jawaban yang diberikan; 3.) kemampuan peserta didik dalam menuliskan kembali ide orang lain menggunakan bahasanya sendiri; dan 4.) Kemampuan peserta didik dalam memberikan tanggapan untuk ide atau jawaban kepada peserta didik yang lain. 


\section{METODE}

Penelitian ini merupakan deskriptif dengan pendekatan kualitatif. Penelitian ini bersifat deskriptif karena akan mendeskripsikan kemampuan komunikasi matematis tulis siswa Samin dalam memecahkan masalah geometri. Pendekatan kualitatif pada penelitian ini berkaitan dengan analisis data lapangan dengan kemampuan komunikasi matematis siswa Samin dalam memecahkan masalah geomtri tanpa adanya perlakuan apapun. Sugiyono (2013) menyebutkan bahwa penelitian kualitatif dilakukan pada kondisi yang alamiah. Oleh karena itu, pengumpulan data berupa tes tulis, wawancara, rekaman suara, catatan lapangan, dan dokumen resmi lainnya diusahakan tidak memberikan pengaruh apapun terhadap proses alamiah komunikasi matematis tulis siswa Samin dalam memecahkan masalah geometri.

Pemilihan subjek penelitian menggunakan metode purposive sampling, yakni pemilihan subjek penelitian berdasarkan kriteria tertentu meliputi pemilihan sekolah, pemilihan kelas, pemilihan siswa Suku Samin, dan pemberian tes kemampuan matematika. Tempat penelitian adalah salah satu Sekolah Menengah Pertama Negeri di Bojonegoro. Pemilihan sekolah ini berdasarkan hasil penelitian yang sebelumnya telah dilakukan oleh Munawaroh et al. (2015) dan saran Kepala Desa Margomulyo yang menyebutkan bahwa mayoritas masyarakat adat Samin bersekolah di sekolah tersebut. Subjek dalam penelitian ini dipilih dari siswa yang berasal dari masyarakat adat Samin Bojonegoro di salah Satu Sekolah Menengah Pertama Negeri di Bojonegoro pada semester genap tahun ajaran 2018/2019. Subjek penelitian diambil dari masing-masing kategori kemampuan matematika yang dimiliki, yakni satu siswa Suku Samin berkemampuan tinggi, satu siswa berkemampuan sedang, dan satu siswa berkemampuan rendah. Subjek penelitian sebanyak tiga siswa yang selanjutnya disebut secara berurutan S1, S2, dan S3.

Desain dan prosedur penelitian yang digunakan peneliti dalam penelitian ini terdiri dari empat tahap, yaitu: tahap persiapan, pengambilan data, analisis data, dan pembuatan laporan. Teknik pengumpulan data yaitu dengan cara tes tulis dan kegiatan wawancara. Instrumen penelitian yang digunakan dalam penelitian ini, yaitu: soal Tes Kemampuan Matematika (TKM), soal Tes Kemampuan Komunikasi Matematis (TKKM), dan lembar pedoman wawancara. Teknik analisis data yang digunakan dalam penelitian ini adalah analisis data menurut Miles dan Huberman (2009) yang menyebutkan bahwa analisis data meliputi pengambilan data, reduksi data, penyajian data, dan penarikan kesimpulan. Terdapat dua metode triangulasi yang digunakan dalam penelitian ini, yaitu triangulasi metode dan sumber. Triangulasi metode dalam penelitian ini dilakukan dengan cara membandingkan hasil data tertulis dan transkrip hasil kegiatan wawancara dari satu subjek penelitian. Triangulasi sumber dalam penelitian ini dilakukan dengan cara membandingkan hasil data dari subjek penelitian yang berbeda.

Data yang telah diambil, direduksi, dan disajikan dapat disimpulkan berdasarkan indikator ke (1) dan (2) kemampuan komunikasi matematis dalam penelitian ini, yaitu; 1.) Kemampuan siswa dalam menuliskan ide yang dimiliki dengan jelas dan tepat; 2.) Kemampuan siswa dalam menuliskan alasan untuk jawaban yang diberikan; 3.) Kemampuan siswa dalam menuliskan kembali ide orang lain menggunakan bahasanya sendiri; dan 4.) Kemampuan siswa dalam memberikan tanggapan untuk ide atau jawaban siswa lainnya.

\section{HASIL DAN PEMBAHASAN}

Skor kemampuan komunikasi yang ditunjukkan S1, S2, dan S3 pada ID1 berturut-turut adalah sebagai berikut 2, 2, dan 1.67 dengan kategori kemampuan komunikasi matematis tulis berturut-turut, yaitu: sedang, sedang, dan sedang. Sedimikian hingga diperoleh nilai rata-rata dengan skor 1,89 dan kategori kemampuan komunikasi matematis tulis yang dimiliki siswa Samin pada indikator menuliskan ide matematis (penggunaan model matematika, rumus atau simbol) menggunakan bahasa simbol dengan jelas dan tepat untuk menyelesaikan suatu permasalahan sehingga dapat dipahami orang lain tergolong rendah. Jawaban S1, S2, dan S3 pada tes kemampuan matematis dapat dilihat pada Gambar 2, Gambar 3, dan Gambar 4. Skor kemampuan komunikasi yang ditunjukkan S1, S2, dan S3 pada ID2, yakni 2, 2, dan 1 dengan kategori kemampuan komunikasi matematis tulis berturut-turut yaitu: sedang, sedang, dan rendah. Rata-rata skor pada ID2 
adalah 1,67. Dengan demikian, kategori kemampuan komunikasi matematis tulis yang dimiliki siswa Samin pada indikator menuliskan alasan untuk jawaban yang telah diberikan tergolong rendah.

S1, S2, dan S3 pada ID3 berturut-turut mendapatkan skor sebagai berikut 3, 4, dan 1 dengan kategori kemampuan komunikasi matematis tulis berturut-turut, yakni tinggi, sangat tinggi, dan rendah, sehingga nilai rata-rata yang pada ID3 adalah 2,67. Hal ini menunjukkan bahwa kemampuan komunikasi matematis tulis siswa Samin dalam memecahkan masalah geometri pada indikator menuliskan kembali ide orang lain menggunakan bahasanya sendiri tergolong sedang. Skor yang didapatkan subjek penelitian S1, S2, dan S3 pada ID4 berturut-turut, yakni 2, 1, dan 0 dengan kategori kemampuan komunikasi matematis tulis berturut-turut, yakni sedang, rendah, dan sangat rendah. Rata-rata skor yang didapatkan adalah 1 . Hal ini menunjukkan bahwa kemampuan komunikasi matematis tulis yang dimiliki siswa Samin pada indikator mengungkapkan kembali dengan cara menulis tanggapan terhadap ide orang lain tergolong rendah.

Penelitian ini menggunakan subjek penelitian dari latar belakang suku tertentu. Hal ini membuat hasil penelitian ini berbeda dengan penelitian sejenis. Hasil penelitian ini dapat digunakan sebagai dasar pertimbangan pemberian kebijakan atau perlakuan yang tepat untuk memperbaiki tingkat kemampuan matematika yang dimiliki siswa Samin khususnya pada materi geometri. Penelitian ini hanya mengambil subjek penelitian yang berasal dari siswa berjenis kelamin perempuan, sehingga hasil penelitian ini kurang beragam. Pada kasus tertentu subjek penelitian dapat memiliki kemampuan komunikasi matematis tulis yang berbeda pada setiap indikator kemampuan komunikasi matematis tulis. Sebagai contoh pada subjek penelitian kedua (S2) pada penelitian ini. Hasil penelitian menunjukkan bahwa S2 memiliki kemampuan komunikasi matematis tulis yang tergolong sangat tinggi pada indikator menuliskan kembali ide orang lain menggunakan bahasanya sendiri. Namun demikian, memiliki kemampuan komunikasi matematis tulis yang tergolong rendah pada indikator mengungkapkan kembali dengan cara menulis tanggapan terhadap ide orang lain.

$$
\begin{aligned}
& \text { b. <Persegi } \square \text { ini untuk lantai dari kerangka / Pondasi dari } \\
& \text { kerang ka rumah-khas suku Samin tersebut. } \\
& <\text { Jajargenjang untuk kerangka menaruh afau menggantungkut } \\
& \text { kan genting agar menutup atap. } \\
& \text { - Segitiga A untuk kerangka atas }
\end{aligned}
$$

Gambar 2. Jawaban S1 pada Tes Kemampuan Matematis

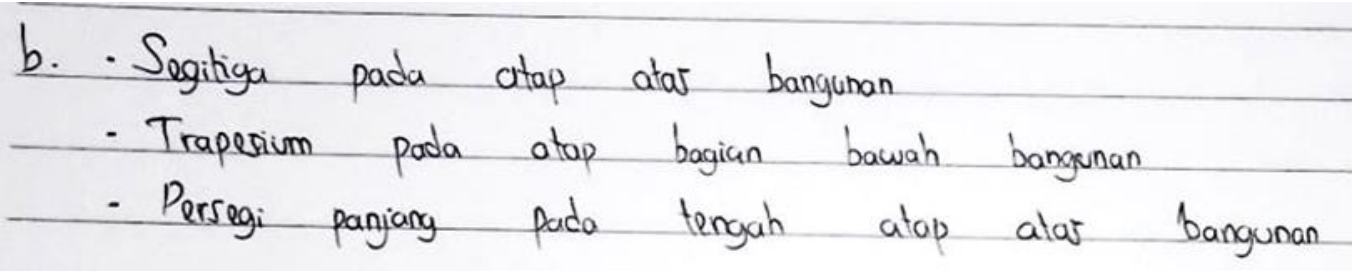

Gambar 3. Jawaban S2 pada Tes Kemampuan Matematis

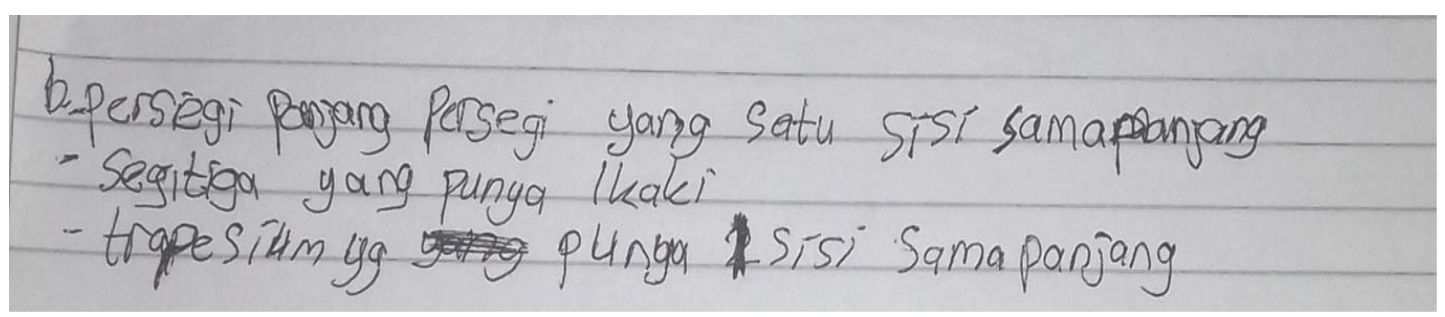

Gambar 4. Jawaban S3 pada Tes Kemampuan Matematis 


\section{SIMPULAN}

Berdasarkan hasil dan pembahasan data penelitian yang telah dilaksanakan oleh peneliti diperoleh simpulan penelitian bahwa kemampuan komunikasi matematis tulis siswa Samin dalam menuliskan ide matematis (penggunaan model matematika, rumus atau simbol) menggunakan bahasa simbol dengan jelas dan tepat untuk menyelesaikan suatu permasalahan, sehingga dapat dipahami orang lain tergolong rendah, kemampuan komunikasi matematis tulis siswa Samin dalam menuliskan alasan untuk jawaban yang telah diberikan tergolong rendah, kemampuan komunikasi matematis tulis siswa Samin dalam menuliskan kembali ide orang lain menggunakan bahasanya sendiri tergolong sedang, dan kemampuan komunikasi matematis tulis siswa Samin dalam mengungkapkan kembali dengan cara menulis tanggapan terhadap ide orang lain tergolong rendah. Berdasarkan penelitian yang telah dilakukan terdapat beberapa saran, yakni: Pertama, menjadikan penelitian ini sebagai dasar penelitian sejenis dengan subjek penelitian berjenis kelamin laki-laki dan perempuan untuk menambah kekayaan informasi hasil penelitian kemampuan komunikasi matematis tulis siswa Samin. Kedua, menjadikan penelitian ini sebagai dasar penelitian sejenis dengan subjek penelitian dari latar belakang suku lain di Indonesia untuk menambah kekayaan informasi kemampuan komunikasi matematis tulis siswa Indonesia dengan latar belakang suku atau masyarakat adat tertentu.

\section{DAFTAR PUSTAKA}

Adhe, K. R. (2014). Penanaman karakter anak usia 5-6 tahun pada masyarakat Samin. Jurnal Pendidikan Usia Dini, 8(2), 275-290. https://doi.org/10.21009/JPUD.082

Agustyaningrum, N. (2012). Implementasi model pembelajaran learning Cycle 5E untuk meningkatkan kemampuan komunikasi matematis siswa kelas IX B SMP Negeri 2 Sleman (Universitas Negeri Yogyakarta). Retrieved from https://eprints.uny.ac.id/7389/

Ardina, F. R., \& Sa'dijah, C. (2016). Analisis lembar kerja siswa dalam meningkatkan komunikasi matematis tulis siswa. Jurnal Pendidikan: Teori, Penelitian, Dan Pengembangan, 1(2), 171180. https://doi.org/10.17977/jp.v1i2.6119

Darkasyi, M., Johar, R., \& Ahmad, A. (2014). Peningkatan kemampuan komunikasi matematis dan motivasi siswa dengan pembelajaran pendekatan quantum learning pada siswa SMP Negeri 5 Lhokseumawe. Jurnal Didaktik Matematika, 1(1), 21-34. Retrieved from http://www.jurnal.unsyiah.ac.id/DM/article/view/1336

Fahradina, N., Ansari, B. I., \& Saiman, S. (2014). Peningkatan kemampuan komunikasi matematis dan kemandirian belajar siswa SMP dengan menggunakan model investigasi kelompok. Jurnal Didaktik Matematika, 1(1), 54-64. Retrieved from http://www.erepository.unsyiah.ac.id/DM/article/view/2077

Hodiyanto, H. (2017). Kemampuan komunikasi matematis dalam pembelajaran matematika. AdMathEdu: Jurnal Ilmiah Pendidikan Matematika, Ilmu Matematika Dan Matematika Terapan, 7(1), 9-18. https://doi.org/10.12928/admathedu.v7i1.7397

Junaedi, I. (2010). Pembelajaran matematika dengan strategi Writing in Performance Tasks (WiPT) untuk meningkatkan kemampuan menulis matematis. Kreano: Jurnal Matematika KreatifInovatif, 1(1), 11-20. https://doi.org/10.15294/kreano.v1i1.218

Jurotun, J. (2015). Meningkatkan komunikasi matematis peserta didik melalui "Disco LeMPer" berbantuan software Geogebra. Kreano: Jurnal Matematika Kreatif-Inovatif, 6(1), 1-6. https://doi.org/10.15294/kreano.v6i1.4471

Laksananti, P. M., Setiawan, T. B., \& Setiawani, S. (2017). Analisis kemampuan komunikasi matematis dalam menyelesaikan masalah pokok bahasan bangun datar segi empat ditinjau dari kecerdasan emosional siswa kelas VIII-D SMP Negeri 1 Sumbermalang. KADIKMA, 8(1), 8896. https://doi.org/10.19184/kdma.v8i1.5268 
Melalatoa, M. J. (1995). Ensiklopedi suku bangsa di Indonesia. Jakarta: Direktorat Jendral Kebudayaan.

Miles, M. B., \& Huberman, A. M. (2009). Qualitative data analysis: An expanded sourcebook (2nd ed.). Retrieved from https://books.google.co.id/books?hl=id\&lr=\&id=U4lU_wJ5QEC\&oi=fnd \&pg=PA10\&dq=Qualitative + data + analysis + Miles\&ots $=\mathrm{kFTH} 2 \mathrm{HVZ1T} \& s i$ $\mathrm{g}=\mathrm{ctEW}$ Fy8_VcHJaSI16_m2hLHAKA\&redir_esc=y\#v=onepage \&q=Qualitative data analysis Miles\&f=false

Muhlizi, A. F. (2014). Revolusi mental untuk membentuk budaya hukum anti korupsi. Jurnal Rechts Vinding: Media Pembinaan Hukum Nasional, 3(3), 453-472. https://doi.org/10.33331/rechtsvinding.v3i3.36

Munawaroh, S., Ariani, C., \& Suwarno, S. (2015). Etnografi masyarakat Samin di Bojonegoro: Potret masyarakat Samin dalam memaknai hidup. Yogyakarta: Balai Pelestarian Nilai Budaya (BPNB) Yogyakarta.

Oktafiya, Y. (2016). Ajaran Samin dan kearifan lokal: Eksistensi masyarakat Samin pada era modernisasi di Dusun Jepang desa Margomulyo kecamatan Margomulyo Kabupaten Bojonegoro (Universitas Islam Negeri Sunan Ampel Surabaya). Retrieved from http://digilib.uinsby.ac.id/13190

Pinasti, V. I. S., \& Irenewaty, T. (2016). Kajian historisitas masyarakat Samin di Blora dalam perspektif pendidikan karakter. Prosiding Seminar Nasional LPPM UNY 2016, 449-459. Retrieved from http://eprints.uny.ac.id/id/eprint/40285

Rassia, V. (2016). Peningkatan kemampuan komunikasi matematis melalui penerapan Lasswell communication model pada siswa kelas VIII SMPN 52 Bandung (Studi eksperimen pembelajaran matematika siswa kelas VIII SMPN 52 Bandung) (Universitas Pasundan). Retrieved from http://repository.unpas.ac.id/13220/

Sugiyono, S. (2013). Metode penelitian pendidikan: Pendekatan kuantitatif, kualitatif, dan $R \& D$ (17th ed.). Bandung: Alfabeta.

Umar, W. (2012). Membangun kemampuan komunikasi matematis dalam pembelajaran matematika. Jurnal Infinity, 1(1). https://doi.org/10.22460/infinity.v1i1.p1-9

Wahyuni, A., \& Pertiwi, S. (2017). Etnomatematika dalam ragam hias Melayu. Math Didactic: Jurnal Pendidikan Matematika, 3(2), 113-118. https://doi.org/10.33654/math.v3i2.61

Wardhani, S. (2008). Analisis SI dan SKL mata pelajaran matematika SMP/MTs untuk optimalisasi pencapaian tujuan (Titik Sutanti, Ed.). Yogyakarta: Pusat Pengembangan Dan Pemberdayaan Pendidik Dan Tenaga Kependidikan Matematika.

Wijayanto, A. D., Fajriah, S. N., \& Anita, I. W. (2018). Analisis kemampuan komunikasi matematis siswa SMP ada materi segitiga dan segiempat. Jurnal Cendekia: Jurnal Pendidikan Matematika, 2(1), 97-104. https://doi.org/10.31004/cendekia.v2i1.36

Yunianto, R. (2014). Keefektifan CTL menggunakan model STAD dan GI ditinjau dari prestasi, komunikasi, dan sikap terhadap matematika. Pythagoras : Jurnal Pendidikan Matematika, 9(1), 31-44. https://doi.org/10.21831/pg.v9i1.9061

Zayzafuun, F. Z. (2016). Pengaruh penggunaan Model Connecting Organizing Reflexting Extending (CORE) dalam pembelajaran matematika terhadap peningkatan kemampuan komunikasi matematis siswa SMA (Universitas Pasundan). Retrieved from http://repository.unpas.ac.id/id/eprint/10716 